\title{
Old English Style
}

Sara M. Pons-Sanz, U. of Westminster (s.ponssanz@westminster.ac.uk)

'ek hlewagastiz holtijaz horna tawido'. Thus reads the fifth-century runic inscription on the so-called Golden Horn of Gallehus (Denmark). It can be translated as 'I, Hlewagastiz, son of Holt (or from [the place called] Holt; or from the forest), made (this) horn'. Its interest for the purposes of this paper lies, not so much in the fact that it gives us examples of (what are probably best described as) North-West Germanic nominal and verbal inflections, ${ }^{1}$ but in that it seems to be an example of alliterative verse with the same governing principles as those characterizing most of the extant Old English poems:

(1) It has four fully stressed syllables, its rhythm being as follows:

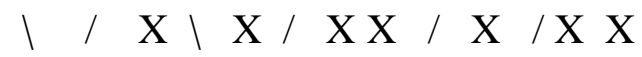

ek hlewagastiz holtijaz horna tawido

One of the features that distinguish the Germanic languages from other Indo-European languages is the fact that the main stress (marked above as /) always falls on the first syllable of the word's root, and, in a poetic line, the words bearing full stress are, generally speaking, lexical words (particularly, nouns, adjectives and some adverbs, while verbs vary in their character: infinitives and participles tend to bear one of the main stresses in the half-line, whereas finite forms may or may not do so; see Momma 1997). The number of syllables

\footnotetext{
${ }^{1}$ On the language of the inscription, see Nielsen $(1998,52-55)$.
} 
bearing secondary stress and unstressed syllables (marked above as \and X, respectively) varies from line to line, or rather, from half-line to half-line. Accordingly, so does the rhythm of each half-line. Yet, despite the potential for variation, there seems to have been only a limited number of acceptable rhythmical types in Old English, which most scansion scholars tend to reduce to five (although, as expected, these types admit some internal variation in connection with the number of syllables not bearing the main stress). The following examples represent the basic types.

(a) Type A, with two feet with the stressed-unstressed pattern:

$$
\text { / } \mathrm{X} / \mathrm{X}
$$

beaga bryttan ('dispenser of rings'; Beowulf, 35a)

(b) Type B, with a reversal of Type A:

$$
\mathrm{X} / \mathrm{X} /
$$

unbliðe sæt ('sat sorrowful'; Beowulf, 130b)

(c) Type C, which combines Type A and Type B:

$$
\mathrm{X} / / \mathrm{X}
$$

on bearm scipes ('in the bosom of the ship'; Beowulf, 35b)

(d) Type D, with the two stressed syllables at the beginning of the half-line:

$$
\text { / } / 1 \mathrm{X}
$$


leof leodcynning ('beloved king of people’; Beowulf, 54a)

(e) Type E, with a main stress at the beginning and end of the half-line:

$$
\text { / } \mathrm{X} \times /
$$

murnende mod ('mourning mind'; Beowulf, 50a) ${ }^{2}$

(2) The first three syllables with full stress in the Gallehus inscription are linked through alliteration, or phonetic similarity at the beginning of a word (marked in bold above), whereas the fourth syllable bearing a main stress does not participate in such aural connection. Notably, in Old English poetry, while a consonant needs to alliterate with the same consonant (and the clusters /sp, st, sk/ with the same cluster), a vowel can alliterate with any other vowel, a peculiarity that has puzzled generations of Old English scholars.

Particularly if holtijaz can be translated as 'son of holt', the inscription may also include an example of variation, a common feature in Old English poetry which consists in referring to an element of the sentence in different terms (in this case, a personal name and a patronymic). This text, then, is a very clear indication of the fact that the general governing principles of Old English poetry go back to Proto-Germanic times, and helps us explain why Old English poems are so structurally similar to, for instance, the Old Norse eddic poems. ${ }^{3}$ Interestingly, though, Thomas Bredehoft has shown that such principles changed overtime,

\footnotetext{
${ }^{2}$ For an edition of Beowulf, see Mitchell and Robinson (1998). For a more thorough account of the traditionally accepted Old English rhythmical types and their combinations, see Bliss, (1958) and Scragg (1991). See, however, Bredehoft (2005) for a reconsideration of the traditional patterns.

${ }^{3}$ On the Germanic background of Old English poetry, see further Magennis (2011, 36-44).
} 
with late Old English poems allowing extrametrical syllables to appear before any initial foot, stressed and unstressed syllables to combine in patterns previously unacceptable, alliteration to link any two syllables (including lines with a AABB pattern), and rhyme to link half-lines (see further Bredehoft, 2005, and 2010, 34-35). The author of the late-tenth- or earlyeleventh-century poem The Battle of Maldon, for instance, seems to have been fairly keen on such rhymes, which may or may not be based on grammatical endings: e.g. 'Byrhtnoð mapelode, bord hafenode' (1. 42; 'Byrhtnoth spoke, raised his shield') and 'æfre embe stunde he sealde sume wunde' (1. 271; 'at almost every moment he gave out some wound'). ${ }^{4}$

Yet, Old English poets were not the only ones to change and adapt the structuring features of Old English poetry. As is widely known, prose writers, especially legal and religious authors, also saw the potential of such devices to grab their audience's attention and did not hesitate to incorporate them into their texts. ${ }^{5}$ Well-known for their use of poetic rhythms, alliteration and other aural effects are Abbot Ælfric of Eynsham (d. ca1010) and Archbishop Wulfstan II of York (d. 1023), to the extent that some of their compositions are sometimes printed in poetic format. ${ }^{6}$ In fact, on the basis of lexical similarities between what he identifies as a poem on Malcolm, king of Scotland, and his wife St. Margaret inserted in the 1067-annal of the D-version of the Anglo-Saxon Chronicle and some Ælfrician rhythmical

\footnotetext{
${ }^{4}$ See further Dance (2006). For an edition of this poem, see Scragg (1981).

${ }^{5}$ On the style of Old English laws, see Bethurum (1932b). On the use of alliteration in religious prose, see Funke (1962b) and Blake (1969).

${ }^{6}$ On Ælfric's alliterative rhythmical prose, see Bethurum (1932a) and Lipp (1969). On Wulfstan's style, Funke (1962a), Orchard (1992) and Dance (2004).
} 
passages, Bredehoft $(2010,36-38)$ has recently argued that at least some of the abbot's nearcontemporaries might have perceived him as a poet. ${ }^{7}$

The practice of incorporating seemingly poetic devices was not restricted to the best wellknown homilists, though, but was fairly common in the late Old English period, albeit, admittedly, to a lesser extent than in their compositions. An anonymous homily recorded in mid-eleventh-century Oxford, Bodleian Library MS Junius 85 (fols $2^{\mathrm{v}}$ and $12^{\mathrm{r}}-17^{\mathrm{r}}$ ), which is one of a series of Old English texts presenting an address of a soul to its body, offers us some good examples of the localized use of such aural effects: ${ }^{8}$

...pu eart deofles hus, forðan ðu deofles willen worhtest, pu wære yrres $\underline{\underline{h y}} \underline{\underline{\text { de }}}$ and oferhydig (11. 11-12).

('you are the house of the devil, because you carried out the devil's will; you are a guardian of anger and proud')

Pu wære godes brytta, forðon ðu $\underline{\underline{\text { Godes }}}$ willan worhtest, pu pæt georne beeodest, dagum and neahtum. (11. 34-35) ${ }^{9}$

\footnotetext{
${ }^{7}$ See further Bredehoft $(2004,107)$, where he concludes that Ælfric was 'Anglo-Saxon England's most prolific poet'.

${ }^{8}$ On this tradition, see Znojemská (2007) and Siebert (2008).

${ }^{9}$ For an edition of the homily, see Healey (1973, 324-40). The two souls' addresses have also been edited by Willard (1935, 961-63). Even though Willard's edition is more easily accessible, he did not edit the whole homily; therefore, the quotations in this paper follow Healey's edition. This text has the short title HomM 14.2 (Healey) in the Complete Corpus of Old English.
} 
('You were a dispenser of good, because you carried out God's will; you did that eagerly, during day- and nighttime')

In this homily we have not one but two souls speaking to their bodies: first a soul that has been condemned to eternal damnation reprimands its morally corrupt body, and then a soul that can enjoy eternal life thanks its pure counterpart. Alliteration (bold) and other aural devices not infrequent in Old English texts such as homoioptoton or grammatical rhyme (underlined with a dotted line), and paronomasia or word-play based on words that are similar but not identical (doubly underlined) help the homilist enhance the associations and contrasts that highlight the key message of the homily: ${ }^{10}$ it is through the actions that you perform that you show whether you follow God or the devil and, accordingly, whether you will enjoy eternal salvation or punishment in the afterlife. Such message, fully in keeping with the doctrine of deeds, makes the homily a perfect companion to The Vision of St Paul, which is sandwiched in between its two parts in the manuscript. ${ }^{11}$

The fact that the fate of one's soul is closely intertwined with bodily actions is further emphasized by the use of personal pronouns: 'Ic ðe eft onfo, and pu me, and wit ðonne butu sculon beon birnende in ðæm ecan fyre' (11. 3-4; 'I will take hold of you again, and you of me, and then we shall both burn in the eternal fire'). The dual pronoun wit is not frequently found in Old English texts, but, when it does appear, it tends to emphasize the special connection between those it refers to. Bragg (1989) explains that in Old English poetry only certain kinds of couples are joined by a dual pronoun: two males who are kinsmen, comrades

${ }^{10} \mathrm{OE}$ god 'good' and God 'God' were homographs, but not homophones, as they differed in the length of their root vowel (long and short, respectively). On the common use of paronomasia in Old English literature, see further Frank (1972).

${ }^{11}$ On the textual context of the homily, see Healey (1978). 
or adversaries, a brother and a sister, and a woman and her husband (in that direction, not a man and his wife; cp. Hall 1981). These relationships could be metaphorically interpreted as well. That is the case in The Dream of the Rood, where the cross can be heard using the first person dual pronoun to refer to itself and Christ because it presents itself metaphorically as both Christ's retainer and wife, as representative of the Christian Church: 'Bysmeredon hie unc butu ætgædere' (1. 49a; 'they mocked us both together'). ${ }^{12}$ Similarly, the relationship between a soul and its body could be understood as one of kinship, as suggested by the introduction to the two speeches that make up the late-tenth-century Old English poem $\underline{\text { Soul }}$ and Body I, recorded, like The Dream of the Rood, in Vercelli, Biblioteca Capitolare MS CXVII (also known as the Vercelli Book):

Huru, ðæs behofað hæleða æghwylc pæt he his sawle sið sylfa gepence, hu pæt bið deoplic ponne se deað cymeð, asyndreð pa sybbe pe ær samod wæron, lic ond sawle' (11. 1-5a) ('Listen, it is necessary for every man that he thinks for himself about the journey of his soul, how terrible it will be when death comes, (and) severs the kinsmen that were together before, body and soul' $)^{13}$

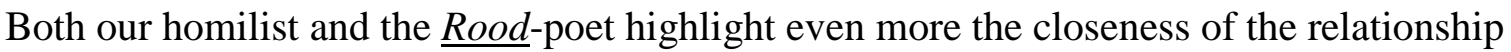
between the two entities (soul and body, cross and Christ) by supplementing the dual pronoun with OE $\underline{\text { butu }}$ 'both'. Admittedly, Old English authors do not seem to have been able to

\footnotetext{
${ }^{12}$ For an edition of The Dream of the Rood, see Swanton (1996).

${ }^{13}$ For an edition of this poem, see Moffat (1990).
} 
replace the dual pronouns with their plural counterparts, but they could avoid their use. Thus, we can assume that authors had a specific purpose in mind when making this linguistic choice.

As noted by Frank $(1994,93)$, the homilist makes the content of two aforementioned rhythmical passages stand out even more by including in them two terms, $\underline{\text { hyrde }}$ 'guardian, prince' and $\underline{\text { brytta }}$ 'dispenser, prince', which can be considered to be typically poetic (cp. 1 . 35a in Beowulf quoted above). ${ }^{14}$ Both terms appear fairly frequently in formulaic expressions, i.e. recurrent phrases that usually make up a half-line on their own and that admit some variation: e.g. Beowulf records the following formulas with $\underline{\text { hyrde }}$ as the head term: folces hyrde 'guardian of people' in 11. 610a, 1832a, 1849a, 2644b and 2981a; fyrena hyrde 'master of crimes' in $1.750 \mathrm{~b}$; hordes hyrde 'guardian of the hoard' in $1.887 \mathrm{a}$; wuldres hyrde 'prince of glory' in 1. 931b; huses hyrdas 'guardians of the dwelling-place' in 1.1666a; sawele hyrde 'guardian of the soul' in 1. 1742a; rices hyrde 'guardian of the kingdom' in 11. 2027a and 3080a; hringa hyrde 'guardian of rings' in 1. 2245a; beorges hyrde 'guardian of the burrow' in $1.2304 \mathrm{~b}$; cumbles hyrde 'guardian of the battle standard' in 1. 2505b; and froetwa hyrde 'guardian of treasures' in 1. 3133b. In the past the centrality of formulas in the Old English poetic language was taken as a clear indication of the texts' oral composition (the so-called 'oral-formulaic theory'). However, this simplistic approach has nowadays been rejected, as it has been shown that formulas are also an important component of poems that are not likely to

${ }^{14}$ Notably, these poetic terms do not appear in the somewhat reduced version of the souls' speeches in a homily on the fourth Sunday after Epiphany (HomS 6 (Ass 14) in the Complete Corpus of Old English); see Assmann (1964, 164-69). Compare: 'Gehyr nu, earma lichama, pu eart deofles hus, forpam pu deofles willan worhtest and godes lare forhogedest' (11. 81-82; 'Listen now, wretched body; you are the devil's house because you carried out the devil's will and rejected God's teaching'). 
have been produced orally (see O’Brien O’Keeffe, 1990, 98-103; Godden, 1992, 502-04; Lester, 1996, 75-77; Orchard, 1997, 103-09; and Acker, 1998).

This homilist was not alone either in wanting to exploit the poetic ring of such terms in a non-poetic text. Frank points out that the use of characteristically poetic terms in homiletic works might be partially attributable to the fact that these texts tend to include direct and reported speeches, these forms of discourse apparently favouring the use of poetic terms more than narrative contexts. After all, 'God, Christ, saints, angels, souls, and scripture speak more poetically than ordinary men; and the attributes of holiness attract poetic language' (Frank, 1994, 91). Indeed, it is widely known that both Ælfric and Wulfstan exploited the stylistic possibilities of a number of poetic terms and their power to grab the audience's attention. Such terms include simplexes (e.g. $\underline{\text { metod }}$ 'creator, God'), compounds (e.g. whuldorðrym 'heavenly glory', earmsceapen 'unfortunate, miserable', and $\underline{\text { ergewyrht }}$ 'former work, deed of old', a term that our homilist uses in 1.73) and collocations (e.g. rodores wealdend 'ruler of the sky'; see Godden, 1980; Chapman, 2002b; and Bredehoft, 2009, 28-38 and ch. 5).

Interestingly, the Old English lexicon includes some terms that are in the main restricted to prose works (e.g. pytt 'pit, hole, well, grave'), others that are more often than not recorded in poetic works, and others that seem to have had a different meaning in poetry and prose (e.g. $\underline{\text { wlenco }}$ had a positive connotation in poetry, meaning 'high spirits, bravado', and a negative connotation in prose, meaning 'pride, arrogance'); the members of the last group tend to have a more specific meaning in prose and a rather more generalizing or metaphorical meaning in poetry (e.g. $\underline{\text { mere }}$ meant 'lake, pond, pool' in prose and 'sea' in poetry'; see Stanley, 1971; Frank, 1994, 89-90; and Cronan, 2003, particularly 505-06 on $\underline{\text { brytta }}$ ).

Poetic words are not the only means through which this author wanted his / her message to hit target, though. Aware of the content and genre of the text, s/he also included a number of terms that might have sounded homiletic-y to his / her audience: e.g. hellewite 'hell-torment' 
(11. 16, 21, 77 and 105), synnlust 'desire to sin' (1. 39), oferdrincere 'drunkard' (1. 112), unrihthoemedfremmere 'adulterer' (1. 113), the collocation fela yfela 'many evil (deeds)' (1. 7) and the appellative formula men ða leofestan 'most beloved people' (11. 26, 71 and 93). All these terms and structures are recorded in the main in homiletic and confessional works, as well as in the legal works of Archbishop Wulfstan, which have a strong homiletic character (see Lawson, 1992; and Wormald, 1999, and 2004). Yet, while unrihthaemed 'adultery' is a fairly common term in those works, unrihthoemedfremmere is only recorded in the homily under analysis, as is one of the components of this compound: the verbal noun fremmere 'committer' (cp. fremman 'to make, do, commit'). This hapax legomenon is a reminder of the lexical flexibility exhibited by the extant Old English texts. Old English poets are frequently credited with extending the language's vocabulary through nonce compounds, many of them tautological. ${ }^{15}$ To them compounds were very appealing for a number of reasons, as summarized by Chapman (2002b, 409): (1) they increased the repertoire of words that could be used in alliterative position and also enlarged the list of near-synonyms that could be used for the purpose of variation; (2) because of their stress pattern, they lent themselves particularly well to the demands of Old English meter (see above); (3) they provided authors with lexical examples of what Robinson (1985) calls the appositive style (i.e. the juxtaposition of words, concepts, images, etc.) that characterizes Old English poetry without the need for any linking element, thus increasing its general lexical density; ${ }^{16}$ (4) they helped to elevate the poetic tone of the passage because of their suggestiveness (see further Brady,

${ }^{15}$ The presence and coinage of compounds is commonly presented as one of the key features of Old English poetry; see, for instance, Scragg (1991, 65-67) and Shippey (1972, ch. 4). ${ }^{16}$ On the lexical density of Old English poetry, achieved partially because of the lower incidence of prepositions and other grammatical terms than in Middle English poetry, see Lester (1996, 47-48). 
1979, and 1983). However, unrihthamedfremmere points very strongly to the fact that such creativity was not restricted to the realms of poetry; again, the need to make an impact on their audience seems to have led homilists (Archbishop Wulfstan probably being their best example) to go along the same path as poets. ${ }^{17}$ Our homilist could have used the rather more common term in homiletic writings unrihthamere 'adulterer', but that compound does not include as direct a reference to the concept of action, which the homilist is keen to emphasize in keeping with the text's general message. Furthermore, it may not be utter chance that this hapax legomenon is associated with the semantic field of vice and crime, homilists (again, Wulfstan in particular!) being highly creative from a lexical perspective when talking about that semantic field (cp. Schwyter, 1996, 46-47, 49-50 and 151-58). Notably, though, when making such generic classifications as above and talking about Old English authors' lexical creativity, we need to remember that the size of the extant corpus of Old English texts is rather small and that poetic works make up less than $10 \%$ of the corpus. ${ }^{18}$ Therefore, adverbs such as seemingly, apparently, possibly, etc. have to be taken as implied when we use adjectives like poetic or creative. Yet, these pointers are helpful in giving us possible hints as to the effects that particular lexical choices might have had in the minds of an Anglo-Saxon audience.

We have, then, a homilist at pains to emphasize, on the one hand, the direct impact that bodily actions have on the after-life of one's soul, and, on the other, the very clear contrast between the fates of a saved and a condemned soul. There are some additional indications of those concerns. The close association between a body's behaviour and its soul's afterlife is

${ }^{17}$ On Wulfstan's compounds, see Chapman (1995, 1998, and 2002a), Pons-Sanz (2004) and Davis-Secord (2008).

${ }^{18}$ The website of the Complete Corpus of Old English describes the size of the corpus as 'almost five times the collected words of Shakespeare'. 
further highlighted by the frequent use of forhwon 'why, for what reason' and forðcem ( $\underline{\text { Øe }})$ 'because; for that reason' in the speeches of the two souls: e.g.

Ponne cwep seo sawl, wa me, forpæm ic pa awirgedan pinc mid ðe lufode, wa me, forðam ic ða toweardan pingc ne gemunde, wa me, forðæm pe ic me hellewite ne ondred, wa me, forðam pe ic heofona rice ne lufode, wa me, forðæm pe ic gepafode ealle ða yfel pe pu dydest (1l. 13-18)

('Then said the soul: Woe is me, because through you I loved those forbidden things; woe is me, because I did not care for future things; woe is me, because I did not fear hell-torment; woe is me, because I did not love the kingdom of heaven; woe is me, because I tolerated all the evil that you did') ${ }^{19}$

We have seen in the two rhythmical passages cited above that parallelism is a key device for highlighting the contrast between the two soul-body pairs and, indeed, this figure of speech is widely used throughout the homily: e.g.

Ic wæs Godes dohter and ængla swistor gescapen, and pu me hafæst forworht, pæt ic am deofles bearn and deoflum gelic (11. 21-23)

('I was made God's daughter and the sister of angels, and you have done me wrong, so that I am the child of the devil and similar to devils')

\footnotetext{
${ }^{19}$ This passage must have been perceived as being particularly powerful, as it constitutes, with very few modifications, the core of the condemned soul's address to its body in HomS 6 (Ass 14); see Assmann (1964, 164-69, 11. 84-89).
} 
Ic wæs Godes dohter and ængla swystor, and pu <me> hafast gemedemod monegum sipum, and for ðinum gewyrhtum, ic eom in heofona rice (11. 63-65).

('I was God's daughter and the angels' sister, and you have respected me on many occasions and for your deeds I am in the kingdom of heaven')

Nowhere is the contrast between right and wrong more clearly presented than in 11. 75-92 of the homily, where the audience are given a list of God's teaching and the devil's misteaching. The lines are presented in a list format so as to facilitate the interpretation of the passage.

God ælmihtig us læreð and laðað to heofona rice.

Diofol us lærað and wile forlæran and eac forlædan to hellewitum.

God ælmihtig us cigeð to heofona rice.

Deofol us laðað to wite and beswicep to deape.

God ælmihtig us lærað wæccan and gebedu.

Diofol us lærað slæp and slæcnesse.

God ælmihtig us lærap fæstan.

Diofol us lærað oferfylle and untidætas.

God ælmihtig us lærað rummodnesse.

Diofol us lærap gitsunga.

God ælmihtig us lærað clænnesse.

Diofol us lærap derne geligro.

God ælmihtig us lærap lipnesse and gefeohtsumnesse.

Diofol us lærað yrre and unrotnesse.

God ælmihtig us lærað eadmodnesse.

Diofol us lærað ofermetto. 
God ælmihtig us lærað sibbe and wynsumnesse.

Diofol us lærað unsibbe and wrohte.

('God almighty teaches us and invites us to the kingdom of heaven. The devil teaches us and wants to seduce us and mislead us to the hell-pains. God almighty summons us to the kingdom of heaven. The devil invites us to punishment and deceives us to death. God almighty teaches us vigil and prayer. The devil teaches us sleepiness and laziness. God almighty teaches us to fast. The devil teaches us gluttony and untimely eating. God almighty teaches us kindness. The devil teaches us avarice. God almighty teaches us chastity. The devil teaches us fornication. God almighty teaches us gentleness and joyfulness. The devil teaches us anger and sadness. God almighty teaches us humility. The devil teaches us pride. God almighty teaches us peace and pleasantness. The devil teaches us strife and contention'). ${ }^{20}$

The rhetorical figure of anaphora (or the repetition of the same word at the beginning of neighbouring verses or clauses) is not the only device at work here that aims to paint a blackand-white picture in the audience's minds. Equally important in bringing the teachings of God and the devil against each other are the use of alliteration and derivation. On some occasions, alliteration works on its own: e.g. the /s1/ cluster emphasizes the sluggishness of the devil's followers ( $\underline{\text { slexp }}$ and sleacnes in 1. 80), while the main and secondary stresses in eadmodnes make us contrast it with the vices that sandwich it: yrre and ofermetto (11. 88-90). Similar echoic effects exist between the devil's and God's messages and their consequences in 11. 78-79: wite contrasts with $\underline{\text { waccan }}$, while the presence of $/ \mathrm{b} /$, albeit not constituting

\footnotetext{
${ }^{20}$ A slightly reduced version of this catalogue of teachings can be found in HomS 6 (Ass 14); see Assmann (1964, 164-69, 11. 102-11).
} 
alliteration strictly speaking, brings together beswicep and gebedu (cp. eadmodnes and unrotnes in 11. 88-89).

Perhaps even more interesting are those cases where word-formation processes, affixation in particular (hence, necessarily, in tandem with alliteration), highlight the differences between the two messages. The prefixes $\underline{\text { ofer-, }} \underline{\text { for }}$ - and $\underline{u n}$ - help to stress that the devil's misteaching and the vices that characterize those who follow it should be understood as excesses and wrongdoings, actions that go against the expected behaviour; accordingly, their effects are also presented as the mirror image of what we could and should enjoy. Think about 11. 75-76, where divine teaching and leadership are placed in direct contrast to their corrupted counterparts: laeran vs forlaran and, because of their echoic character, laðian vs forlaedan. Similarly, the peace and inner happiness that one enjoys when following God (sib, 1. 91) has nothing to do with the strife, with both oneself and others ( $\underline{\text { unsibb }}, 1.92)$, and unhappiness ( $\underline{\text { unrotnes }}, 1.88)$ that one suffers under the devil's influence. We are to understand that gluttony ( $\underline{\text { oferfylle }}$ and untidat, 1.82 ), pride (ofermetto, 1. 90; uneaðmodnes, 1 . 106), drunkenness ( $\underline{\text { oferdrincere 'drunkard', 1. 112) and adultery (unrihthoemedfremmere }}$ 'adulterer', 1. 113) are some of the vices that have led the unfaithful (ungeleafful, 1. 2) body to its condemnation, a state shared by its incorporeal counterpart (forwyrcan 'to condemn'; see forworht in 11. 6, 8, 22 and 25). Given that, as stated a number of times, this whole homily calls attention to the relationship between one's actions and after-life, it is only right that the concept of condemnation be presented, from a lexical perspective, as the direct result of wrong actions (cp. OE $\underline{\text { wyrcan }}$ 'to perform, do, make').

On very few occasions are good behaviour and its practitioners associated with a term containing one of the aforementioned prefixes. When this is the case, given the prefixes' strong connection with those in the devil's camp, we have to assume that the word has been very carefully chosen. Unsynnig 'sinless, righteous' in 1.30 offers us a very good example of 
the crafty uses that Old English writers found for litotes, a stylistic device much to their taste whose intended effect still remains to be fully understood. ${ }^{21}$ The adjective appears as an epithet for the virtuous body the first time that its soul addresses it. We have just witnessed the condemned soul rebuke its body for its current state, and unsynnig puts the reason why this other soul can enjoy its salvation right in the spotlight. The contrast could not be clearer, but, as we might expect from someone who is very keen to make lexical relations help transmit his / her message, this is not enough for this homilist. Instead, this litotes is just one of the means through which we are asked to compare the two sets of body-soul relations, their actions and their fates, which are hinted at right from the first time a soul addresses its body:

Sawl and ðus cweð, gehyrstu, hearda lichoma? Pu ungeleaffulla, sceawa on me to hwylcere susle ðu eart toweard. (11. 1-3)

('And a soul thus said: 'Do you hear, cruel body? You, unbelieving, behold through me the torments you are heading to')

... gehyrstu, eadiga lichama, and pu unsynnig? [...] Geherstu, goda lichoma and pu geleaffulla? (11. 30-33)

('Do you hear, blessed and righteous body?' [...] Do you hear, good and faithful body?')

\footnotetext{
${ }^{21}$ On the very frequent use of litotes and understatement more generally in Old English poetry, see Bracher (1937), Schuman and Hutchins (1960), Harris (1988), Schaefer (1997, 111-15), and Frank (2006).
} 
A verbal echo (together with syntactic parallelism and the anaphora based on gehyrstu which runs through the two addresses) leads us to compare and contrast the initial corrupted body with the newly introduced virtuous counterpart, and we are shown the right alternative (geleafful) to the divergent behaviour implied by ungeleafful.

There are no known rhetorical treatises written in Old English nor was the study of classical rhetorical treatises part of the curriculum of the average Anglo-Saxon classroom. However, this homily, like many other Old English texts, shows that the educated AngloSaxons were familiar with the tropes and schemes of the classical tradition (which they probably learned as part of their study of grammar as a tool for religious exegesis), and were able to bring together inherited and newly acquired techniques in order to transmit very powerful messages. ${ }^{22}$

This paper has attempted to explain and exemplify the main stylistic features that characterize Old English literary compositions. Alliteration, apposition, variation, poetic compounds and the use of formulas brought the work of the Anglo-Saxon scops close to the poetic views of their Germanic ancestors. Yet, the Anglo-Saxons moved their native poetic language forward by incorporating as well figures of speech more commonly associated with the classical tradition. When prose started to be composed, particularly as a result of King Alfred's (d. 899) educational policies, this successful amalgamation was adapted to new literary contexts, as we have seen. The arrival of a French-speaking elite after the Norman Conquest (1066) moved the epicentre of the mainstream poetic style away from the Germanic models and closer to the Medieval Latin tradition: rhyme and syllabic count replaced alliteration as the main structural devices in poetry, and the appeal of some traditional features (e.g. variation and poetic compounds) plummeted, while other stylistic trends, such

\footnotetext{
${ }^{22}$ On the Anglo-Saxons' knowledge of the rhetorical figures of the classical tradition, see Barlett (1935), Campbell (1967), Knappe (1998), and Steen (2008).
} 
as the exploitation of loanwords, gained ground. A new chapter in the history of English stylistics had started.

\section{References}

Acker, Paul (1998), Revising Oral Theory: Formulaic Composition in Old English and Old

Icelandic Verse, Garland Studies in Medieval Literature, 16. New York, NY, and London: Garland.

Assmann, Bruno (1964), Angelsächsische Homilien und Heiligenleben, Bibliothek der angelsächsischen Prosa, 3 (Kassel), reprinted with a supplementary introduction by Peter Clemoes. Darmstadt: Wissenschaftliche Buchgesellschaft.

Barlett, Adeline Courtney (1935), The Larger Rhetorical Patterns in Anglo-Saxon Poetry. New York, NY: Columbia University Press.

Bethurum, Dorothy (1932a), 'The Form of Ælfric's Lives of Saints', Studies in Philology, 29, 515-33.

— (1932b), 'Stylistic Features of Old English Laws', Modern Language Review, 27, 263-79.

Blake, N. F. (1969), 'Rhythmical Alliteration', Modern Philology, 67, 118-24.

Bliss, Alan J. (1958), The Metre of Beowulf. Oxford: Oxford University Press.

Bracher, Frederick (1937), 'Understatement in Old English Poetry', $\underline{P M L A}$, 52, 915-34.

Brady, Caroline (1979), “Weapons” in Beowulf: An Analysis of the Nominal Compounds and the Poet's Use of them', Anglo-Saxon England, 8, 79-141.

—, "Warriors" in Beowulf: An Analysis of the Nominal Compounds and the Poet's Use of them', Anglo-Saxon England, 11, 199-246.

Bragg, Lois (1989), 'Old English Dual Pronouns and their Poetic Uses', Language and Style, $22,337-49$. 
Bredehoft, Thomas A. (2004), 'Ælfric and Late Old English Verse', Anglo-Saxon England, $33,77-107$.

— (2005), Early English Metre. Toronto: University of Toronto Press.

- (2009), Authors, Audiences and Old English Verse. Toronto: University of Toronto Press.

— (2010), 'Malcom and Margaret: The Poem in Annal 1067D', in Alice Jorgensen (ed.), Reading the Anglo-Saxon Chronicle: Language, Literature, History, Studies in the Early Middle Ages, 23. Turnhout: Brepols, pp. 28-48.

Campbell, J. J. (1967), 'Knowledge of Rhetorical Figures in Anglo-Saxon England', $\underline{\text { Journal }}$ of English and Germanic Philology, 66, 1-20.

Chapman, Don W. (1995), 'Stylistic Use of Nominal Compounds in Wulfstan's Sermons'. Unpublished doctoral dissertation, University of Toronto.

— (1998), 'Motivations for Producing and Analysing Compounds in Wulfstan's Sermons', in Jacek Fisiak and Marcin Krygier (eds), Advances in English Historical Linguistics (1996), Studies and Monographs, 112. Berlin: Mouton de Gruyter, pp. 15-21.

— (2002a), 'Germanic Tradition and Latin Learning in Wulfstan's Echoic Compounds', Journal of English and Germanic Philology, 101, 1-18.

— (2002b), 'Poetic Compounds in the Vercelli, Blickling and Wulfstan Homilies', Neuphilologische Mitteilungen, 103, 409-21.

The Complete Corpus of Old English in Machine Readable Form (TEI Compatible Version), ed. by Antoinette di Paolo Healey, <http://ets.umdl.umich.edu/o/oec/>, accessed on 16 July 2012.

Cronan, Dennis (2003), 'Poetic Meanings in the Old English Poetic Vocabulary', English Studies, 84, 397-425. 
Dance, Richard (2004), 'Sound, Fury and Signifiers, or Wulfstan's Language', in Matthew Townend (ed.), Wulfstan, Archbishop of York: The Proceedings of the Second Alcuin Conference, Studies in the Early Middle Ages, 10. Turnhout: Brepols, pp. 29-61. —, (2006), 'Pær wearð hream ahafen': A Note on Old English Spelling and the Sound of $\underline{T h e}$ Battle of Maldon', in Hugh Magennis and Jonathan Wilcox (eds), The Power of Words: Anglo-Saxon Studies Presented to Donald G. Scragg on his Seventieth Birthday, Morgantown, WV: West Virginia University Press, pp. 278-317.

Davis-Secord, Jonathan (2008), 'Rhetoric and Politics in Archbishop Wulfstan's Old English Homilies', Anglia, 126, 65-96.

Frank, Roberta (1972), ‘Some Uses of Paronomasia in Scriptural Old English Verse', Speculum, 47, 207-26.

— (1994), 'Poetic Words in Late Old English Prose', in Malcolm Godden et al. (eds), From Anglo-Saxon to Early Middle English: Studies Presented to E. G. Stanley. Oxford: Clarendon Press, pp. 87-107. — (2006), ‘The Incomparable Wryness of Old English Poetry', in John Walsmley (ed.), Inside Old English: Essays in Honour of Bruce Mitchell. Oxford: Blackwell, pp. 59-73. Funke, Otto (1962a), 'Some Remarks on Wulfstan's Prose Rhythm', English Studies, 43, 311-18.

— (1962b), 'Studien zur alliterierenden und rhythmisierenden Prosa in der älteren altenglischen Homiletik', Anglia , 80, 9-36.

Godden, Malcolm R. (1980), ‘Ælfric’s Changing Vocabulary’, English Studies, 61, 206-23. — (1992), 'Literary language' in Richard M. Hogg (ed.), The Cambridge History of the English Language, Vol. 1: The Beginnings to 1066. Cambridge: Cambridge University Press, pp. 490-535. 
Hall, J. R. (1981), 'Duality and the Dual Pronoun in Genesis B', $\underline{\text { Papers on Language and }}$ Literature, 17, 139-45.

Harris, A. Leslie (1988), 'Litotes and Superlative in Beowulf', English Studies, 69, 1-11.

Healey, Antoinette di Paolo (1973), 'The Vision of St Paul'. Unpublished doctoral dissertation, University of Toronto.

- (ed.) (1978), The Old English Vision of St. Paul, Speculum Anniversary Monographs, 2. Cambridge, MA: Medieval Academy of America.

Knappe, Gabriele (1998), 'Classical Rhetoric in Anglo-Saxon England', Anglo-Saxon England, 27, 5-29.

Lawson, M. K. (1992), 'Archbishop Wulfstan and the Homiletic Element in the Laws of Æthelberht II and Cnut', English Historical Review, 107, 565-86.

Lester, G. A. (1996), The Language of Old and Middle English Poetry. Houndsmill: Macmillan.

Lipp, Frances Randall (1969), ‘Ælfric’s Old English Prose Style’, Studies in Philology, 66, 689-718.

Magennis, Hugh (2011), The Cambridge Introduction to Anglo-Saxon Literature. Cambridge: Cambridge University Press.

Mitchell, Bruce, and Fred C. Robinson (eds) (1998), Beowulf: An Edition. Oxford: Blackwell. Moffat, Douglas (ed. and trans.) (1990), The Old English Soul and Body. Woodbridge: D. S. Brewer.

Momma, H. (1997), The Composition of Old English Poetry, Cambridge Studies on AngloSaxon England, 20. Cambridge: Cambridge University Press.

Nielsen, Hans Frede (1998), The Continental Backgrounds of English and its Insular Development until 1154. Odense: Odense University Press. 
O’Brien O'Keeffe, Katherine (1990), Visible Song: Transitional Literacy in Old English

Verse. Cambridge: Cambridge University Press.

Orchard, A. P. McD. (1992), 'Crying Wolf: Oral Style and the Sermones Lupi', Anglo-Saxon England, 21, 239-64.

— (1997), 'Oral tradition', in Katherine O’Brien O'Keeffe (ed.), Reading Old English Texts. Cambridge: Cambridge University Press, pp. 101-23.

Pons-Sanz, Sara M. (2004), 'For Gode and for worolde: Wulfstan's Differentiation of the Divine and Worldly Realms through Word-Formation Processes', English Studies, 85, 281-96.

Robinson, Fred C. (1985), Old English and the Appositive Style. Knoxville, TN: The University of Tennessee Press.

Schaefer, Ursula (1997), 'Rhetoric and Style', in Robert E. Bjork and John D. Niles (eds.), A Beowulf Handbook. Exeter: University of Exeter Press, pp. 105-24.

Schuman, R. Baird, and H. Charles Hutchins (1960), 'The un- Prefix: A Means of Irony in Beowulf', Modern Philology, 57, 217-22.

Schwyter, J. R. (1996), Old English Legal Language: The Lexical Field of Theft, NOWELE Supplement Series, 15. Odense: Odense University Press.

Scragg, Donald G. (ed.) (1981), The Battle of Maldon, Old and Middle English Texts. Manchester: University of Manchester Press.

— (1991), 'The Nature of Old English Verse', in Malcolm R. Godden and Michael Lapidge (eds), The Cambridge Companion to Old English Literature. Cambridge: Cambridge University Press, pp. 55-70.

Shippey, T. A. (1972), Old English Verse. London: Hutchinson.

Siebert, Eve E. (2008), 'Body and Soul Poems in Old and Middle English Literature'. Unpublished doctoral dissertation, St. Louis University. 
Stanley, E. G., 'Studies in the Prosaic Vocabulary of Old English Verse', Neupholologische Mitteilungen, 72, 385-418.

Steen, Janie (2008), Verse and Virtuosity: The Adaptation of Latin Rhetoric in Old English Poetry, Toronto Old English Series. Toronto: University of Toronto Press.

Swanton, Michael (ed.) (1996), The Dream of the Rood, new ed. Exeter: Exeter University Press.

Willard, Rudolph (1935), 'The Address of the Soul to the Body', PMLA, 50, 857-83.

Wormald, Patrick (1999), 'Archbishop Wulfstan and the Holiness of Society', in his Legal Culture in Early Medieval West: Law as Text, Image and Experience. London: Hambledon, pp. 225-51.

—, 'Archbishop Wulfstan: Eleventh-Century State Builder', in Matthew Townend (ed.), Wulfstan, Archbishop of York: The Proceedings of the Second Alcuin Conference, Studies in the Early Middle Ages, 10. Turnhout: Brepols, pp. 9-27.

Znojemská, Helena (2007), 'Medieval English Soul and Body Literature’, Litteraria Pragensia, 34, 20-40. 